\title{
CORRECTION
}

\section{Correction to: The biological tests used in acute-phase of inflammation in bone infection Clinical study}

\author{
Jaime Jose Morales de Cano ${ }^{1,2} \cdot J^{\text {J. Cabo }}{ }^{1} \cdot$ A. Fernandez Sabate ${ }^{1} \cdot$ R. Clos $^{1} \cdot$ M. Villena ${ }^{1} \cdot$ J. Ariza ${ }^{1}$
}

Published online: 28 May 2021

○) Springer-Verlag France SAS, part of Springer Nature 2021

Correction to: Eur J Orthop Surg Traumatol (1995) 5: 33-36 https://doi.org/10.1007/BF02716211

The original version of this article unfortunately contained a mistake. The family name of author "Jaime Jose Morales de Cano" was incorrect.

The correct given name and family name should be:

Given name: Jaime Jose

Family name: Morales de Cano

Publisher's Note Springer Nature remains neutral with regard to jurisdictional claims in published maps and institutional affiliations.

The original article can be found online at https://doi.org/10.1007/ BF02716211.

Jaime Jose Morales de Cano

15449jmc@comb.cat

1 Service of Orthopedic Surgery and Traumatology, Ciudad Sanitaria y Universitaria de Bellvitge, Hospitalet de

Llobregat, Barcelona, Spain

2 Balmes $3951^{\circ}$ 2a., SP-08022 Barcelona, Spain 